\title{
Edukasi Bahaya Sampah Plastik dengan Metode Bercerita pada Anak-Anak Terdampak Siklon Tropis Seroja di Desa Waisika Kabupaten Alor
}

\section{Faryda Veronica Lamma Koly*1, Aksa Naema Mooli², Novita Ayu Matoneng Oilsana ${ }^{3}$, Imanuel Yoel Sulumasi ${ }^{4}$, Petrus Jilbert Milians Pulla ${ }^{5}$}

\author{
1Program Studi Kimia, Fakultas MIPA, Universitas Tribuana Kalabahi, Indonesia \\ ${ }^{2}$ Program Ilmu Teologi, Fakultas Teologi, Universitas Kristen Satya Wacana, Indonesia \\ ${ }^{3}$ Forum Anak Alor, Indonesia \\ ${ }^{4}$ Program Studi Biologi, Fakultas MIPA, Universitas Nusa Cendana, Indonesia \\ ${ }^{5}$ Program Studi Destinasi Wisata, Fakultas Interdisiplin, Universitas Kristen Satya Wacana, Indonesia \\ *e-mail: faryda.veronica.l.k@gmail.com ${ }^{1}$, mooliaksa17@gmail.com ${ }^{2} \_$noayumatoneng@gmail.com ${ }^{3}$, \\ imanuelsulumasi@gmail.com ${ }^{4}$, petrusjilbertpulla@gmail.com ${ }^{5}$
}

\begin{abstract}
Abstrak
Siklon tropis Seroja menyerang beberapa lokasi di Indonesia pada bulan April 2021 lalu, termasuk Desa Waisika, Kabupaten Alor. Bantuan sembako dan cemilan yang dibagikan ke masyarakat sebagian besar berkemasan plastik. Apabila tidak dimanajemen dengan baik, maka dapat menimbulkan dampak buruk bagi lingkungan dan kesehatan manusia. Oleh karena itu edukasi mengenai bahaya sampah plastik dengan metode yang menyenangkan dan upaya penanggulangan secara sederhana perlu dilakukan. Telah dilakukan kegiatan pengabdian kepada masyarakat tentang edukasi bahaya sampah plastik bagi anak-anak terdampak siklon seroja di Desa Waisika Kabupaten Alor. Kegiatan ini bertujuan untuk menyadartahukan bahaya sampah plastik bagi lingkungan hidup dan secara langsung atau tidak langsung bagi manusia. Metode yang digunakan yaitu bercerita dengan tiga sesi yang terdiri dari sesi pengenalan keanekaragaman hayati disekitar Desa Waisika, penyampaian bahaya sampah plastik melalui drama singkat, dan upaya penyelamatan lingkungan dari sampah plastik melalui pembuatan ecobricks. Kegiatan ini menghasilkan peningkatan pengetahuan bagi anak-anak secara konseptual dan aplikatif.
\end{abstract}

Kata kunci: Alor, Bercerita, Ecobricks, Sampah Plastik, Seroja

\section{Abstract}

Tropical cyclone Seroja struck several locations in Indonesia in April 2021, including Waisika Village, Alor Regency. Most of the food aid and snacks distributed to the community were packaged in plastic. If not managed properly, it can have a negative impact on the environment and human health. Therefore, education about the dangers of plastic waste with a fun method and simple countermeasures needs to be done. Community service activities have been carried out on education about the dangers of plastic waste for children affected by the Seroja cyclone in Waisika Village, Alor Regency. This activity aims to raise awareness about the dangers of plastic waste for the environment and directly or indirectly for humans. The method used is storytelling with three sessions consisting of an introduction to biodiversity around Waisika Village, conveying the dangers of plastic waste through short plays, and efforts to save the environment from plastic waste through the manufacture of ecobricks. This activity resulted in an increase in knowledge for children conceptually and applied.

Keywords: Alor, Ecobricks, Plastic Waste, Seroja, Storytelling

\section{PENDAHULUAN}

Kabupaten Alor merupakan salah satu dari 21 kabupaten di Provinsi Nusa Tengga Timur dengan luas wilayah daratan $2.864,64 \mathrm{~km}^{2}$, luas perairan $10.773,62 \mathrm{~km}^{2}$, panjang garis pantai 287,10 km (BPS, 2015). Wilayah Kabupaten Alor menjadi salah satu wilayah dengan resiko tinggi terhadap bencana alam. Bencana alam yang paling sering dialami yaitu gempa bumi (dengan atau tanpa tsunami atau tanah longsor) sejak tahun 1982, 1987, 1991, 2004, dan 2015 (BPS, 2015) hingga tahun 2021. Selain itu, bencana alam lain berupa banjir bandang pertama kali terjadi pada tanggal 4 April 2021 lalu. Bencana ini disebut dengan Siklon Tropis Seroja yang memakan korban 25 orang meninggal, 20 orang hilang, 25 orang luka-luka, 175 rumah rusak berat, 180 rusak sedang dan 180 rusak ringan (Petrus, 2021). Sumber lain menyajikan data 
bahwa bencana ini memakan korban mencapai hampir 200 orang dengan ratusan rumah terendam banjir dan tertimbun longsor (Suryani, 2021). Desa Waisika merupakan salah satu dari beberapa lokasi terdampak badai tersebut. Bencana alam pada saat ini berpotensi menghasilkan sampah dalam jumlah besar. Sampah dapat berasal dari barang-barang milik masyarakat atau terbawa aliran air dari lokasi lain. Biasanya setelah bencana, terdapat sejumlah bantuan baik dari pemerintah maupun swasta yang tiba ke lokasi bencana. Hal ini juga terjadi di Desa Waisika. Para relawan dan para donatur dari dalam dan luar NTT silih berganti sampai ke tiap lokasi bencana. Bantuan yang diterima berupa sembako, pakaian, peralatan makan, bahan bangunan dan bantuan psikososial bagi orang tua dan anak-anak. Berdasarkan hasil observasi langsung dan melalui pengamatan di media sosial, bantuan sembako dan makanan ringan untuk anak-anak yang sampai ke masyarakat di lokasi bencana didominasi oleh kemasan plastik sekali pakai. Dengan laju masuknya bantuan ke setiap lokasi begitu tinggi disertai tingkat konsumsi produk berkemasan plastik relatif meningkat dari biasanya, maka laju peningkatan sampah plastik di desa meningkat. Apabila tidak dikelola dengan baik, ditambah fasilitas manajemen yang belum memadai, maka sampah pasca bencana tersebut dapat berdampak buruk bagi lingkungan dan kesehatan masyarakat serta dapat mempengaruhi proses pemulihan secara keseluruhan (Brown, Milke, \& Erica, 2011).

Keberadaan sampah plastik yang jumlahnya semakin meningkat menimbulkan keresahan bagi dunia. Berdasarkan hasil penelitian sebelumnya [Koly et al., 2021], konsentrasi sampah di Kabupaten Alor yang diwakili oleh data sampah pesisir menunjukkan nilai yang tinggi dan didominasi oleh sampah plastik kemasan. Meskipun demikian, masih banyak masyarakat yang belum menyadari bahaya dari sampah plastik. Sampah plastik sulit diurai dalam tanah. Plastik dapat terdegradasi melalui fotodegradasi, pemanasan dan pembakaran menjadi mikroplastik (Klein et al., 2018). Apalagi dengan kebiasan membakar sampah plastik yang masih dimiliki oleh sebagian besar masyarakat Indonesia. Salah satu upaya yang dapat dilakukan untuk menyadartahukan bahaya sampah plastik yaitu dengan sosialisasi. Fokus utama saat ini yaitu kepada anak-anak, karena pengetahuan dan karakter cinta lingkungan sangat penting ditanamkan saat masih kecil.

Tim relawan psikososial oleh alumni Forum Anak Alor melakukan kunjungan ke Desa Waisika selama hampir 2 bulan di dua posko bencana. Kunjungan ini bertujuan untuk menghibur anak-anak terdampak bencana yang sebagian besar mengalami trauma. Aktivitas trauma healing yang dilakukan beranekaragam seperti bermain, bernyanyi, mendongeng, dan beberapa edukasi seperti pentingnya tas siaga bencana dan bahaya sampah plastik bagi lingkungan hidup. Tujuan dari kegiatan ini yaitu mengajak anak-anak untuk menghargai keanekaragaman hayati yang ada disekitar dan ikut ambil bagian dalam memeliharanya, menyampaikan bahaya sampah plastik bagi makhluk hidup melalui drama singkat, dan mengajak anak-anak untuk mengolah sampah plastik secara mandiri dengan membuat ecobricks.

Ecobrick adalah botol PET yang dipadatkan dengan plastik bekas yang bersih dan kering dengan alat bantu stik bambu. Ecobrick dibuat dengan kepadatan tertentu untuk membuat blok bangunan atau furniture yang dapat digunakan kembali. Andriastudi dkk. (2019) menghitung potensi ecobrick dalam mengurangi sampah plastik rumah tangga di kecamatan Pontianak Barat. Hasil yang diperoleh yaitu ecobricks memiliki potensi yang besar dalam pengurangan sampah plastik yaitu 77\%. Palupi dkk. (2020) menyarankan pembuatan ecobricks sebagai media pembelajaran untuk anak usia dini. Selain menyenangkan, metode ini memiliki manfaat yang beragam. Selain berkontribusi pada pengurangan sampah plastik, selama pembuatan ecobricks diharapkan dapat merangsang aspek perkembangan anak seperti perkembangan fisik terutama perkembangan motorik halus, kognitif, emosi sosial, kreativitas, dan seni.

\section{METODE}

Kegiatan ini dilakukan pada tanggal 1 bulan Mei tahun 2021, bertempat di Desa Waisika tepatnya Dusun 1 dengan metode pembelajaran anak-anak. Pelaksanaan kegiatan dilakukan 
melalui penyampaian teori dalam bentuk bercerita sambil mewarnai dan melalui drama, praktek dan tanya-jawab serta diselingi bernyanyi. Metode ini diadopsi dan dimodifikasi dari buku workshop anak oleh Indrawati (2019). Instruktur pada masing-masing sesi yaitu mahasiswa, aktivis peduli anak dan dosen kimia Universitas Tribuana Kalabahi. Peralatan dan bahan yang digunakan berupa media karton sketsa "Hutan Waisika", pensil crayon, stiker gambar hewan, topeng bergambar hewan-hewan darat dan laut, botol plastik kosong, stik bambu, sampah plastik, neraca, stopwatch dan alat tulis. Selain itu, dilibatkan juga 11 orang sebagai pemeran tokoh fabel.

Kegiatan yang dilakukan untuk menjawab tujuan pertama yaitu pengenalan keanekaragaman hayati melalui kolase hewan pada karton sketsa hutan. Aktivitas untuk penyampaian bahaya sampah plastik dilakukan melalui drama fabel oleh tokoh fabel, dan kompetisi ecobricks pada sesi terakhir dilakukan untuk mengajarkan metode sederhana dalam mengolah sampah plastik agar tidak berserakan di lingkungan dan mencemari lingkungan, serta merusak keanekaragam hayati yang ada di sekitar.

\section{HASIL DAN PEMBAHASAN}

\subsection{Pengenalan keanekaragam hayati}

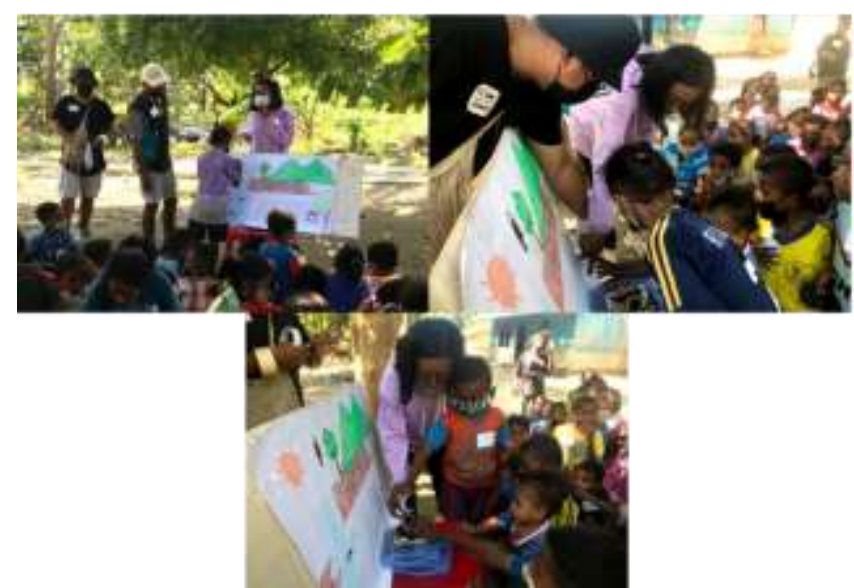

Gambar 1. Sesi pengenalan keanekaragaman hayati

Sesi pertama bertujuan untuk mengenalkan kepada anak-anak keanekaragaman hayati yang ada di sekitannya nya. Anak-anak dibimbing oleh seorang instruktur dalam membuat kolase berupa kenampakan geografis yang terdiri dari gunung, sawah, sungai, pondok, pohon, rerumputan dan laut serta aneka hewan yang hidup di dalamnya (Gambar 1). Setelah kolase jadi, instruktur menyampaikan pentingnya merawat dan melestarikan lingkungan sekitar demi keberlangsungan keanekaragaman hayati. Tanya-jawab juga dilakukan untuk mengajak anakanak mengevaluasi macam tindakan yang dapat mengancam kehidupan alam. Aneka jenis perlakuan negatif terhadap hewan yang disebutkan seperti tidak memberi makan hewan peliharaan, memukul dan menendang hewan, serta mengusir hewan liar dengan cara yang tidak ramah. Setelah itu, instruktur mengajak anak-anak untuk pelan-pelan mengubah kebiasaan yang dilakukan atau dengan sabar menegur orang lain yang melakukannya. Hal ini disambut baik oleh anak-anak dengan memberikan respon positif.

\subsection{Edukasi bahaya sampah plastik}

Sesi selanjutnya bertujuan untuk menyajikan fakta dampak sampah plastik bagi beberapa organisme hidup melalui drama fabel singkat. Tokoh karakter yang berperan antara lain sapi, kucing, anjing, babi, kambing, ayam, bebek, dugong, lumba-lumba dan penyu, serta 
burung elang sebagai prolog sekaligus tokoh protagonis dan tikus sebagai pemeran antagonis. Alur dari drama yaitu pengenalan, konflik dan klimaks, leraian dan penyelesaian.

\subsubsection{Pengenalan}

Pada tahap ini, burung elang merangkap nataror memperkenalkan keberadaan Hutan Waisika sambil mengaitkannya dengan aktivitas pada sesi 1 sekaligus memperkenalkan diri dan perannya sebagai pengamat keberlangsungan hutan. Setelah pengenalan seting, dilanjutkan dengan pengenalan tokoh fabel lainnya selain tikus. Setiap karakter yang dikenalkan wajib menirukan suara atau gerak-gerik yang biasa dilakukan oleh hewan dimaksud. Kunjungan awal burung elang menampilkan kondisi penghuni hutan yang dalam keadaan baik. Tahap pengenalan diakhiri dengan narasi bahwa burung elang kembali mengudara dan mengamati hutan dari ketinggian.

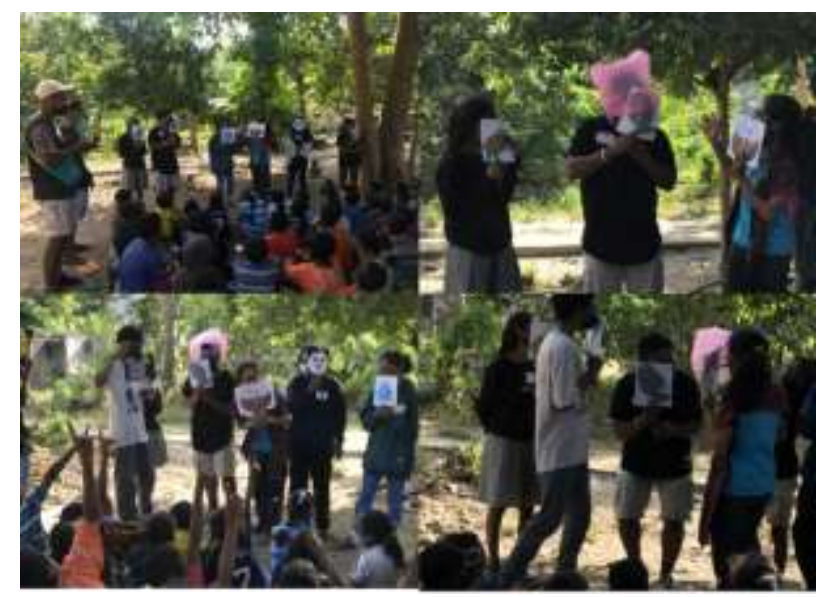

Gambar 2. Sesi drama fabel

\subsubsection{Konflik dan Klimaks}

Beberapa hari kemudian, burung elang kembali menyapa penghuni hutan satu per satu dan ternyata semua dalam keadaan sakit (Tabel 1) dan terperangkap plastik pada lokasinya masing-masing. Burung elang menjanjikan untuk mencari pertolongan dan obat herbal untuk membantu menyembuhkan penghuni hutan Waisika. Dalam perjalanan mencari bantuan, burung elang melihat tikus yang sedang makan dan buang sampah plastik sembarangan di sungai, sawah dan membakar sampah plastik. Burung elang menegur dan menyampaikan bahwa tindakan tikus tersebut menyebabkan masalah untuk penghuni hutan lainnya.

Tabel 1. Jenis hewan dan permasalahannya

\begin{tabular}{cl}
\hline Hewan & \multicolumn{1}{c}{ Kesulitan } \\
\hline Sapi & Batuk-batuk akibat menghirup asap bakaran sampah \\
& plastik \\
Kambing & Gatal-gatal akibat lingkungan main dikotori sampah \\
& plastik dan bekas bakaran plastik \\
Babi & Sakit perut karena makan makanan terkontaminasi plastik \\
Anjing & Muntah-muntah karena minum air terkontaminasi plastik \\
Ayam & Karet tersangkut di kerongkongan \\
Bebek & Puntung rokok tersangkut di kerongkongan \\
Kucing & Sesak napas akibat menghirup asap bakaran plastik \\
Dugong & Tersangkut pada kantong plastik \\
Penyu & Sedotan menancap pada hidung \\
Lumba-lumba & Terjerat tali pancing \\
\hline
\end{tabular}




\subsubsection{Penyelesaian}

Tikus menyadari kesalahannya dan bersedia membantu burung elang untuk mencari obat herbal. Keduanya mengunjungi penghuni hutan yang sedang sakit untuk menolong dan meminta maaf.

\subsection{Kompetisi Ecobricks}

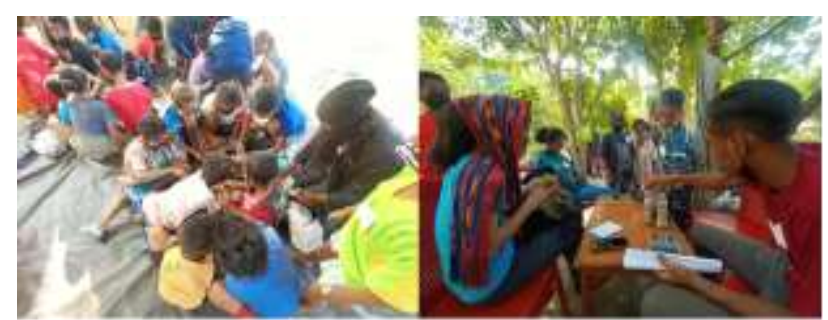

Gambar 3. Sesi pembuatan dan penilaian ecobricks

Pada sesi ketiga, anak-anak diarahkan oleh instruktur untuk mengolah sampah plastik menjadi ecobricks untuk mencegah plastik bekas menjadi sampah yang berserakan di lingkungan dan kemudian berdampak negatif bagi kelangsungan makhluk hidup di sekitarnya (Gambar 3). Aktivitas ini dilakukan dalam bentuk kompetisi. Anak-anak dibagi dalam 4 kelompok dengan salah seorang pendamping pada tiap kelompok. Alat dan bahan dibagikan secara merata bagi tiap kelompok kemudian instruktur memberikan arahan bagaimana membuat ecobricks. Sampah plastik yang digunakan pada kegiatan ini dikumpulkan oleh anakanak sebelum pertemuan. Antusias anak-anak terlihat sejak dari pengumpulan sampah.

Instruktur kemudian memberi aba-aba untuk memulai kompetisi dalam rentang waktu 1 jam. Pendamping setiap kelompok berperan dalam memberikan arahan lebih lanjut mengenai pembautan ecobricks, selain itu juga mengawasi anak-anak karena menggunakan gunting untuk memotong plastik. Kriteria penilaian ecobricks adalah berat total ecobrick. Kelompok yang juara, baik 1, 2 atau 3 diberikan hadiah. Setelah kompetisi berakhir, instruktur kembali memberikan arahan bagi anak-anak untuk membuat ecobricks di rumah. Anak-anak merespon dengan baik ditandai dengan antusias beberapa anak yang langsung meminta plastik bekas usai kegiatan.

Sebelum kegiatan ini dilakukan, anak-anak biasanya membuang sampah plastik tidak pada tempatnya karena belum memiliki pemahaman tentang dampak sampah plastik bagi lingkungan dan kesehatan manusia. Setelah kegiatan ini dilakukan, anak-anak mulai memiliki kesadaran akan bahaya sampah plastik dan mempunyai pilihan untuk mengolah sampah plastik secara mandiri dengan membuat ecobricks. Dalam kunjungan tim pada hari selanjutnya, beberapa anak mulai membuat ecobricks secara mandiri di rumah.

\section{KESIMPULAN}

Edukasi bahaya sampah plastik kepada anak-anak dengan metode bercerita berhasil dilakukan di Dusun 1 Desa Waisika. Keberhasilan kegiatan nampak dari antusias anak-anak selama kegiatan dan terdapat beberapa anak yang selanjutnya membuat ecobrick secara mandiri dirumah. Kegiatan dilaksanakan dengan 3 tahapan yaitu pengenalan keanekaragaman hayati di lingkungan sekitar Waisika, drama bahaya sampah plastik dan kompetisi ecobricks. Jumlah anak yang berpartisipasi sebanyak 60 anak.

\section{UCAPAN TERIMA KASIH}

Ucapan terimakasih disampaikan kepada teman-teman relawan dari Forum Anak Alor diantaranya Mira Kiliana Ataupah, Amangda Rifaldi Dama, Ferdinan Rifandi Awang, Febriyanti Lidia Lakamey, Tia Buanama. 


\section{DAFTAR PUSTAKA}

Andriastuti, B.T., Arivin, Arivin., dan Fitria, Laili. (2019). Potensi ecobrick Dalam mengurangi sampah plastik rumah tangga Di kecamatan pontianak barat. Jurnal Teknologi Lingkungan Lahan Basah. Vol. 7. No.2. 05-063.

BPS. (2015). Alor dalam Angka. Kalabahi: Badan Pusat Statistik Kabupaten Alor.

Brown, C., Milke, M., \& Erica, S. (2011). Disaster waste manahement: A review article. Waste Management, 31, 1085-1098. doi:10.1016/j.waswan.2011.01.027

Indrawati, K.P. (2019). "Buku Program Workshop Anak di Kabupaten Alor: Lingkungan Hidup Berkelanjutan Tanpa Sampah Plastik". Jakarta: Saute Books.

Klein, S., Dimson, I., Eubeler, j., \& Knepper, T. P. (2018). Analysis, Occurrence, and Degradation of Microplastics in the Aqueous Environment. In Freshwater Microplastics Emerging Environmental Contaminants? (Vol. 58, pp. 25-49). Switzerland: Springer Open.

Koly, F.V.L., Waskita A. M. and Plaimo P. E. (2021). Marine Litter Composition and Density in Alor Island. Moroccan Journal of Chemistry. 8 S1. 053-063

Petrus, A. (2021, April 8). merdeka.com. https://www.merdeka.com/peristiwa/korban-siklontropis-seroja-di-kabupaten-alor-25-orang-meninggal-dan-20-hilang.html

Palupi, W., Wahyuningsih, S., Widiyastuti, E., Nurjanah, N.E., Pudyaningtyas, A.R. (2020). Pemanfaatan Ecobricks Sebagai Media Pembelajaran Untuk Anak Usia Dini. Dedikasi: Community Service Report. Vol. 2. 28-34.

Suryani, A.S. 2021. Bencana karena cuaca ekstrem di NTT dan NTB. Pusat Penelitian Badan Keahlian. 